\title{
Analysis of the Cesarean Section Unit Cost With the Time-Driven Activity-Based Costing Method: A Narrative Review
}

\author{
Fahmy Abdul Haq ${ }^{1, *}$ Firman Pribadi ${ }^{2}$ Titiek Hidayati $^{3}$
}

\author{
${ }^{1,2}$ Master of Hospital Administration, Universitas Muhammadiyah Yogyakarta, Yogyakarta, Indonesia \\ 3. Family medicine and Public Health Department, Medicine and Health Sciences Faculty Universitas Muhammadiyah \\ Yogyakarta, Yogyakarta, Indonesia \\ *Corresponding author. Email: fahmy.abdul.psc19@mail.umy.ac.id
}

\begin{abstract}
It is necessary to think about a method of determining the cost of a cesarean section that is in accordance with the real conditions in a private hospital so that the hospital does not suffer losses. The research objective was to determine the method of calculating the unit cost of Caesarean section surgery at PKU Muhammadiyah Bantul Hospital based on the Time driven Activity Based Costing method. We conducted a narrative review of various scientific articles that reported the TDABC in cesarean surgery. Search Strategy We searched the Pubmed database, Elsevier and google scholar without language or time restrictions for articles that met the selection criteria. From selected journals, we extract unit cost data or procedure models from all included studies, study designs and methods, including results, conclusions, and limitations. Data extraction results are then presented descriptively and narrated in the results section. The results of the research on the cost of care for benign prostatic hyperplasia using Time Driven Activity Based Costing (TD-ABC) show that. There are variations in patient care unit ccost depending on the type of value chain that each patient passes. Based on the results of previous studies, it is expected that the unit cost of cesarean section using TD-ABC is more in line with reality. Based on the research results, it is expected that TD-ABC can determine the unit cost of cesarean section according to the real conditions in PKU Muhammadiyah Bantul Hospital.
\end{abstract}

Keywords: Unit cost of cesarean section; INA-CBG; TD-ABC; cost analysis; case study

\section{BACKGROUND}

The goal of health development is to increase awareness, willingness, and ability to live a healthy life for everyone to achieve an optimal health degree based on Law of the Republic of Indonesia Number 23 of 1992. The hospital is a health facility that focuses on curative and rehabilitative efforts. These facilities require expensive financing so that not all levels of society can access these facilities. Health financing aims to provide health financing that is continuous or continuous in a sufficient amount and is allocated relatively and provides optimal benefits ${ }^{[1,10]}$.

In the 58th resolution of 2005 in Geneva, the World Health Organization or WHO gave each country a mandate to develop Universal Health Coverage, the State of Indonesia established a National Health Insurance to carry out this mandate. The program through a Social Security Administration Agency or BPJS has been implemented in Indonesia since January 1, 2014. BPJS Kesehatan pays for the health services of its participants to health facilities, both First Level Health Facilities (FKTP) and Advanced Referral Health Facilities (FKRTL), for example, hospitals ${ }^{[3,4,5]}$. The JKN system is generally like insurance. The government and the community work together to collect funds, which are then returned to the community who need health services at no cost. The payment of health service fees by BPJS for hospitals is carried out using the Indonesian Case Base Groups (INACBGs) case-mix model, which is determined based on a regulation of the Minister of Health. With the enactment of the INA CBGs tariff package, hospital managers must crosssubsidize the non-acting INA CBGs rates against the INA CBGs rates with actions. This cross-subsidy is challenging to implement in hospitals with a high number of treatment services. INA CBGs rates for surgical services such as obstetric gynecology are, on average, lower than real hospital rates. Approximately 18.5 million sectio secaria (SC) procedures are performed worldwide each year. In Indonesia, according to WHO, Indonesia spent around the US \$ $19,532,824$ in $2008^{[6,7,8]}$. Based on Basic Health Research data in 2018, the number of deliveries in private hospitals was $18 \%$ more than that in government hospitals by $15 \%{ }^{[9]}$. The proportion of SC actions increased from $7 \%$ in 2007 to $17 \%$ in $2017^{[10,11]}$. In the 2017 BPJS records for Advanced Level Inpatient Care (RITL), the most cases were Minor Caesarean Surgery, with the number of claims reaching IDR 3 trillion $^{[12,13,14]}$.

The majority of hospitals use a "top-down" accounting system rather than a "bottom-up" approach ${ }^{[15]}$. The top-down approach uses predefined data (e.g., relative value units / RVU) to determine the total cost of health services. The bottom-up approach calculates prices based on the resources used to provide patient care at the hospital. The cost 
calculation using the "bottom-up" approach is more accurate because it identifies each contributor to the cause of costs and calculates the indirect costs needed to support patient care $^{[15,16,17]}$. Traditional ABC is seen as an appropriate method for determining the cost of health services in hospitals. However, the hospital is an industry that operates on a large scale, so that Traditional ABC is difficult to implement ${ }^{[18.19 .20]}$. Time-Driven Activity-Based Costing, or TD-ABC, is a managerial accounting approach introduced in 2004 by Kaplan and Anderson. In 2011 at the Head and Neck Center at MD Anderson Cancer Center in Houston calculating costs with TDABC reduced costs for technical staff by $12 \%$ and reduced costs for professional staff by $67 \%$. The calculation of costs with the TDABC model is superior for complex systems ${ }^{[14,21,22]}$. It allows easier calculation changes both the time or the value of the resources used with justified results. TDABC cost analysis is a simple and more accurate cost calculation model than Traditional ABC cost analysis $^{[23,24,25]}$. Besides, the Indonesian obstetrics and gynecology associations and hospital associations throughout Indonesia assess the Time-Driven Activity-Based Costing (TDABC) for the tariff grouping system to be more in line with reality in private hospitals ${ }^{[23,24,25,26]}$. Therefore, a cost analysis based on the TDABC model on caesarean section surgery in the PKU Muhammadiyah Bantul Hospital Operating Room is needed to determine more accurate costs. Besides, these costs can be used to compare the applicable hospital rates and rates based on INA-CBG so that strategic steps can be taken for better management decision making. The research objective was to review the method of calculating the unit cost of the Caesarean section. surgery based on the time-driven Activity-Based Costing method ${ }^{[27]}$.

\section{METHOD}

\subsection{Desain and Goal}

We conducted a narrative review of various scientific articles that reported the TD-ABC in cesarean surgery. The study's main objective was to understand the method of calculating Caesarean section surgery's unit cost based on the time-driven Activity-Based Costing method.

\subsection{Pico, keyword and Search strategy}

Researcher search journals and literature with keyword guides derived from PICO. We conducted literature searches in March, April, and early May 2020. The literature is searched using a combination of search terms: fuzzy TD$\mathrm{ABC}, \mathrm{TD}-\mathrm{ABC}$, Cesarean surgery, $\mathrm{ABC}$, traditional $\mathrm{ABC}$, cost precision.

Search Strategy We searched the Pubmed database and google scholar without language or time restrictions for articles that met the selection criteria. The Journal of searching results is screened from the title and abstract and then classified in the original journal article, systematic review, guideline, short communication, and letter to the editor. The author takes selected journals from original papers and short communication[28].

\subsection{Selection Methods}

Inclusion Criteria are systematic review, RCT or observational reports published by peer-reviewed journals; Population: Cesarean surgery cost; Intervention: TD-ABC, fuzzy TD-ABC; Comparison: $\mathrm{ABC}$, conventional $\mathrm{ABC}$; Outcome: cost precision. The exclusion criteria are the guideline text and the theoretical model or narrative review. From the selected title, the selection is based on established criteria. Two authors independently selected journals based on predetermined criteria, and then they discussed to determine the selected journals ${ }^{[29]}$.

\subsection{Data extraction, analysis, and Presentation}

From selected journals, we extract the procedure of data gathering, total time, cost total from all included studies, authors, year of publication, journals, and location; details of the study population and interventions; study designs and methods, including randomization procedures (RCT) and statistical analysis; results, conclusions, and limitations. Data extraction results are then presented descriptively and narrated in the results section. The research results will be processed and declared as unit cost based on the service value chain and service time and cesarean section at PKU Bantul Hospital. The research results on the cost of care for benign prostatic hyperplasia using Time-Driven Activity-Based Costing (TD-ABC) show that. There are variations in inpatient care unit cost depending on the value chain that each patient passes. Based on previous studies results, it is expected that the unit cost of the cesarean section using TD$\mathrm{ABC}$ is more in line with reality ${ }^{[30,31,32]}$.

\section{RESULTS AND DISCUSSION}

\subsection{Search history and the number of hits and the number of titles according to the purpose.}

Researchers have conducted searching in three database centers, namely Google Scholar, Pubmed, and Elsevier. The results of the literature search are presented in table 1.

Table 1. Data search results for libraries in three database centers, PubMed, Google scholar, and Elsevier.

\begin{tabular}{|c|c|c|c|}
\hline No & Database address & $\begin{array}{c}\text { Number of } \\
\text { hits }\end{array}$ & $\begin{array}{c}\text { No Selected } \\
\text { title }\end{array}$ \\
\hline 1 & Pubmed & 1 & 1 \\
\hline & $\begin{array}{c}\text { Systematic review meta- } \\
\text { analisis2 }\end{array}$ & 0 & 1 \\
\hline & $\begin{array}{c}\text { Narrative Review and } \\
\text { guidance }\end{array}$ & 0 & 5 \\
\hline 2 & Original articles & 1 & 2 \\
\hline & $\begin{array}{c}\text { Systematic review/ a meta- } \\
\text { analysis }\end{array}$ & 15 & 3 \\
\hline & Original articles & 30 & 0 \\
\hline & $\begin{array}{c}\text { Case report/short } \\
\text { communication }\end{array}$ & 164 & 0 \\
\hline & Letter to editor & 1156 & 0 \\
\hline 3. & Elsevier & 696 & 0 \\
\hline & Original article & 107 & \\
\hline
\end{tabular}




\begin{tabular}{|c|c|c|}
\hline $\begin{array}{c}\text { Systematic review and book } \\
\text { chapter }\end{array}$ & 358 & 0 \\
\hline
\end{tabular}

The search results on PubMed found one title according to the research objectives. From the literature search on google scholar, there were 1350 hits. From the netted titles, which are by the research objectives, there are five titles, three libraries in original articles, and two libraries as reviews. A search on Elsevier found 696 titles that were netted, but none of the titles matched the research objectives

\subsection{Author, year, library title, and extraction data}

According to the objectives, the title selection results finally obtained four literature pieces by the research objectives. The four literature titles and the results of extraction data are presented in Table 2.

Based on Table 2, it is known that three of the four libraries are derived from research results in Indonesia (thesis), one library is an international journal manuscript. From the three pieces of literature from Indonesia, the research was carried out by private hospitals. One study was conducted in Yogyakarta, and two studies were conducted in Jakarta.

The calculation of the unit cost of the cesarean section with the TDABC method is lower than the hospital's essential unit cost. The unit cost of a cesarean section in private hospitals in Jakarta compared to a cesarean section in private hospitals in Yogyakarta is far different. In general, the results of unit cost calculations using TDABC are more accurate and precise. They can assess service flows and critical loci need vigilance to make it easier for management to evaluate and monitor.

Table 2. Title of literature according to the election results and data extraction results

\begin{tabular}{|c|c|c|c|c|c|}
\hline No & $\begin{array}{c}\text { Authors, } \\
\text { year }\end{array}$ & Titles & Methods & Result & Note \\
\hline 1 & $\begin{array}{c}\text { Santosa, } \\
\text { JC, } \\
2012 .\end{array}$ & $\begin{array}{c}\text { Analisis Penerapan } \\
\text { Time Driven Activity } \\
\text { Based Costing Pada } \\
\text { Perhitungan Harga } \\
\text { Pokok Tarif Jasa } \\
\text { Persalinan Per Kelas } \\
\text { Rumah Sakit ST. } \\
\text { Anna }\end{array}$ & \begin{tabular}{|} 
The case study at \\
the private St Anna \\
hospital Jakarta. \\
Cost calculation \\
using TDABC, the \\
basis for calculating \\
costs in 2011
\end{tabular} & $\begin{array}{l}\text { The cost of giving birth to a } \\
\text { cesarean section for VIP class is } \\
\text { IDR } 26,174,327 \text {, class I IDR } \\
25,514,327 \text {, class II } 22,008,002 \text {, } \\
\text { and type III IDR } 20,153,129 \text {. }\end{array}$ & $\begin{array}{c}\text { Technical } \\
\text { accounting } \\
\text { student of Atma } \\
\text { Jaya University } \\
\text { Jakarta. The } \\
\text { stages of } \\
\text { determining the } \\
\text { costs are not } \\
\text { described in the } \\
\text { abstract. }\end{array}$ \\
\hline
\end{tabular}




\begin{tabular}{|c|c|c|c|c|c|}
\hline 2 & $\begin{array}{c}\text { Faizal } \\
\text { Satria., } \\
2018\end{array}$ & $\begin{array}{c}\text { Analysis of the } \\
\text { calculation of service } \\
\text { costs using a time- } \\
\text { driven activity-based } \\
\text { costing approach at } \\
\text { Muhammadiyah } \\
\text { Hospital Yogyakarta } \\
\text { (PKU) (a case study } \\
\text { of cesarean surgery } \\
\text { procedure) }\end{array}$ & \begin{tabular}{|l|} 
A case study in the \\
central operating \\
room of PKU \\
Hospital, \\
Yogyakarta City. \\
TDABC costing \\
method.
\end{tabular} & $\begin{array}{l}\text { These stages are: 1) Identify the } \\
\text { Cost Pool, 2) Identify the total cost } \\
\text { of each cost pool, 3) Determine the } \\
\text { practical capacity and capacity cost } \\
\text { rate of each cost pool, 4) Determine } \\
\text { the estimated time from the cost } \\
\text { pool in carrying out the activity or } \\
\text { process, and 5) Performing cost } \\
\text { calculations using the TDABC } \\
\text { model and analyzing capacity } \\
\text { utilization. The cost of a cesarean } \\
\text { section without complications } \\
\text { based on TDABC was IDR } \\
2,176,747.3\end{array}$ & $\begin{array}{c}\text { UGM } \\
\text { accounting } \\
\text { master student } \\
\text { thesis. }\end{array}$ \\
\hline 3 & $\begin{array}{c}\text { RJ } \\
\text { Pratiwi, } \\
2017\end{array}$ & $\begin{array}{c}\text { Analysis of the } \\
\text { application of the } \\
\text { time-driven activity- } \\
\text { based costing system } \\
\text { in calculating the cost } \\
\text { of products for } \\
\text { delivery services per } \\
\text { class of PB hospital }\end{array}$ & $\begin{array}{c}\text { A case study at a } \\
\text { private PB hospital } \\
\text { in Jakarta. Costing } \\
\text { using TDABC }\end{array}$ & $\begin{array}{l}\text { The calculation of the cost of } \\
\text { cesarean section services at PB VIP } \\
\text { Class Hospital will result in a } \\
\text { difference of IDR } 11,515,672 \text {, class } \\
\text { I IDR } 11,280,672 \text {, class II IDR } \\
11,089,672, \text { and type III IDR } \\
\text { 11,018,372. Of the determined cost } \\
\text { of goods. The TDABC method can } \\
\text { be used to rationalize the } \\
\text { determination of the cost of hospital } \\
\text { services. }\end{array}$ & $\begin{array}{c}\text { Thesis from an } \\
\text { accounting } \\
\text { student in } \\
\text { Jakarta. }\end{array}$ \\
\hline 4 & $\begin{array}{l}\text { Odhiam } \\
\text { bo, J., } \\
2019\end{array}$ & $\begin{array}{c}\text { Health Facility Cost } \\
\text { of Cesarean Delivery } \\
\text { at a Rural District } \\
\text { Hospital in Rwanda } \\
\text { Using Time-Driven } \\
\text { Activity-Based } \\
\text { Costing }\end{array}$ & \begin{tabular}{|} 
Retrospective \\
study. The study \\
assessed the cost of \\
cesarean delivery at \\
Butaro District \\
Hospital, a rural \\
hospital in the \\
Northern Province \\
of Rwanda.
\end{tabular} & $\begin{array}{l}\text { Ditetapkan } 7 \text { kategori biaya. The } \\
\text { total cost of cesarean delivery was } \\
\text { US } \$ 339 \text {, inclusive of intra- } \\
\text { operative costs of US\$118 }(35 \%) \\
\text { and pre and post-operative costs of } \\
\text { US } \$ 221(65 \%) \text {. The cost of } \\
\text { cesarean delivery ranged between } \\
\text { US } \$ 320 \text { and US } \$ 380 \text { in the lower } \\
\text { and upper bound estimates. }\end{array}$ & $\begin{array}{c}\text { Jurnal } \\
\text { international }\end{array}$ \\
\hline
\end{tabular}

\section{CONCLUSION}

The implementation of the TDABC cost calculation system is faster than using Traditional $\mathrm{ABC}$ and is more straightforward. The use of TDABC can increase the effectiveness of health services and improve the clinical communication system.

\section{AUTHORS' CONTRIBUTIONS}

FAH was involved in designing and collecting data, FP was engaged in composing research designs, collecting data, and writing publication drafts. $\mathrm{TH}$ was involved in data analysis and drafting; FAH, FP, and TH contributed equally to the research design, the implementation of data collection, data processing, and analysis, writing draft publications, and proofreading.

\section{ACKNOWLEDGMENTS}

The researcher thanked LPPM Kemenristek Dikti and LPPM UMY for financial assistance to implement this research activity.

\section{REFERENCES}

[1] Indonesia, R., 2009. Undang-undang Republik Indonesia nomor 36 tahun 2009 tentang Kesehatan. Jkt. Repub. Indones.

[2] Balakrishnan, K., Goico, B., Arjmand, E.M., 2015. Applying cost accounting to operating room staffing in otolaryngology: time-driven activity-based costing and outpatient adenotonsillectomy. Otolaryngol.--Head Neck Surg. 152, 684-690.

[3] Kemenkes, R.I., 2016. Profil Kesehatan Republik Indonesia. Jkt. Kementrian Kesehat.

[4] Heru, A., 2010. Langkah-Langkah Strate-gis Perhitungan Analisa Biaya (Perhitungan Unit Cost) di Rumah Sakit, in: Workshop Penghitungan Tarif Berbasis Unit Cost Di Rumah Sakit, Jakarta. 
[5] Keel, G., Savage, C., Rafiq, M., Mazzocato, P., 2017. Time-driven activity-based costing in health care: A systematic review of the literature. Health Policy 121, 755-763. https://doi.org/10.1016/j.healthpol.2017.04.013

[6] Gibbons, L., Belizán, J.M., Lauer, J.A., Betrán, A.P., Merialdi, M., Althabe, F., 2010. The global numbers and costs of additionally needed and unnecessary caesarean sections performed per year: overuse as a barrier to universal coverage. World Health Rep. 30, 1-31.

[7] Sugiyono, P.D., 2008. Metode penelitian kuantitatif dan kualitatif dan R\&D. Bdg. ID Alf.

[8]Yun, B.J., Prabhakar, A.M., Warsh, J., Kaplan, R., Brennan, J., Dempsey, K.E., Raja, A.S., 2016. Timedriven activity-based costing in emergency medicine. Ann. Emerg. Med. 67, 765-772.

[9] KEMENKES, R., 2018. Hasil utama RISKESDAS 2018. Kementrian Kesehat. Badan Penelit. Dan Pengemb. Kesehat. Jkt.

[10] BKKBN, N.P. and F.P.B., BPS, S.I., Kemenkes, M. of H., ICF, 2018. Indonesia Demographic and Health Survey 2017.

[11] Pemerintah, R.I., 2014. Peraturan Menteri Kesehatan Republik Indonesia Nomor 27 Tahun 2014 Tentang Petunjuk Teknis Sistem Indonesian Case Base Groups (INA-CBGs).

[12] BPJS, 2017. Laporan Pengelolaan Program Dan Laporan Keuangan Jaminan Sosial Kesehatan Tahun 2017.

[13] Odhiambo, J., Ruhumuriza, J., Nkurunziza, T., Riviello, R., Shrime, M., Lin, Y., Rusangwa, C., Omondi, J.M., Toma, G., Nyirimodoka, A., 2019. Health Facility Cost of Cesarean Delivery at a Rural District Hospital in Rwanda Using Time-Driven Activity-Based Costing. Matern. Child Health J. 23, 613-622.

[14] Kaplan, R.S., Anderson, S.R., 2004. Time-driven activity-based costing. Harv. Bus. Rev. 82, 131$138+150$

[15] Martin, J.A., Mayhew, C.R., Morris, A.J., Bader, A.M., Tsai, M.H., Urman, R.D., 2018. Using Time-Driven Activity-Based Costing as a Key Component of the Value Platform: A Pilot Analysis of Colonoscopy, Aortic Valve Replacement and Carpal Tunnel Release Procedures. J. Clin. Med. Res. 10, 314-320. https://doi.org/10.14740/jocmr3350w

[16]Creswell, J.W., 2014. Research design: Qualitative, quantitative, and mixed methods approaches. Sage publications.

[17]Demeere, N., Stouthuysen, K., Roodhooft, F., 2009. Time-driven activity-based costing in an outpatient clinic environment: development, relevance and managerial impact. Health Policy 92, 296-304.

[18] S. Subagyo., 2008. Time-Driven Activity-Based Costing. Akunt. Krida Wacana 8.

[19]M. Nowicki., 2011. Introduction to the financial management of healthcare organizations. Health Administration Press Chicago, IL.

[20] U. Sekaran., R. Bougie., 2013. Research Methods for Business. Res. Methods Bus.
[21]E. J. Blocher., D. E. Stout., G. Cokins., 2011 Manajemen Biaya dengan Penekanan Strategis. Buku Satu. Diterjemahkan oleh David Wijaya. Jakarta: Salemba Empat.

[22]P. Everaert., W. Bruggeman., G. Sarens., S. R. Anderson., Y. Levant., 2008. Cost modeling in logistics using time-driven ABC. Int. J. Phys. Distrib. Logist. Manag.

[23] R. S. Kaplan., M. E. Porter., 2011. How to solve the cost crisis in health care. Harv Bus Rev 89, 46-52.

[24]A. L. Kaplan., N. Agarwal., N. P. Setlur., H. J. Tan., D. Niedzwiecki., N. McLaughlin., M. A. Burke., K. Steinberg., K. Chamie., C. S. Saigal,. 2015. Measuring the cost of care in benign prostatic hyperplasia using time-driven activity-based costing (TDABC), in: Healthcare. Elsevier, pp. 43-48.

[25]R. S. Kaplan.,S. R. Anderson., 2007. Time-driven activity-based costing: a simpler and more powerful path to higher profits. Harvard business press.

[26]F. Kowsari., 2014. Changing in costing models from traditional to performance focused activity based costing (PFABC). Eur. Online J. Nat. Soc. Sci. Proc. 2, 2497-2508.

[27] M. Yusuf., 2016. Metode Penelitian Kuantitatif, Kualitatif \& Penelitian Gabungan.

[28] Z. Azmi., 2018. Time Driven Activity Based Costing dan implementasinya pada jasa perawatan kesehatan. J. Akunt. Dan Ekon. 8, 75-84.

[29]E. C. Harmadi., 2015. Implementation of fuzzy-time driven activity based costing (fuzzy-TDABC) to estimate healthcare service cost in outpatient unit (a case study: Al Irsyad Hospital Surabaya). Institut Teknologi Sepuluh Nopember.

[30]I. Mylonas., K. Friese., 2015. Indications for and risks of elective cesarean section. Dtsch. Ärztebl. Int. 112, 489.

[31]H. Setiaji., 2008. Analisis Biaya Pelayanan Rawat Inap Di Ruang VIP Cendrawasih RSUD Dr. Soeselo Kabupaten Tegal Tahun 2006. Program Pascasarjana Universitas Diponegoro.

[32] P. Kurt., M. Saban., F. Cankaya., M. C. Annac., 2019. time-driven activity-based costing in the ophthalmology department of state hospital: a case study. fresenius Environ. Bull. 28, 2754-2770. 